\section{Seamless sterilisation}

From SciCan, STATIM B is a NEW 6-litre vacuum autoclave for enhanced infection control.

With smart features and enhanced digital capabilities, STATIM B enables smoother workflows and exceptional performance on a small footprint!

$\rightarrow$ Flexible loading options

$\rightarrow$ Shorter cycle times

$\rightarrow$ Maintenance reminders and video tutorials

$\rightarrow$ Programmable features, preheat the chamber before you open.

Sterilised dry-wrapped loads can be delivered in 27 minutes with the STATIM $\mathrm{B}$, and WiFi-enabled technology allows cycle logging, data storage and traceable load release.

SciCan is part of COLTENE the developer and distributer of tools, equipment and materials for upgraded dentistry.

For details on the STATIM B, visit https://www.scican.com/eu/products/ autoclaves/statim-b/. For more on COLTENE, visit www.coltene.com, email info.uk@coltene.com or call 08002545115.

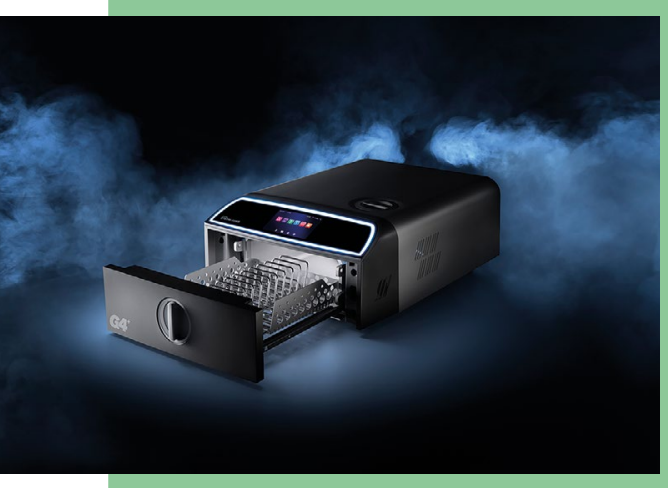

\title{
The sky's the limit
}

For the clinician in pursuit of a happy, fulfilling, and successful career, working and learning go hand in hand, and this is exactly what's on offer at Rodericks Dental.

Educational advancement and career progression opportunities are available to all and tailored by a senior management team comprised of several individuals who have worked as practising clinicians - so you know you will have access to courses designed to help you thrive.

Supplementing the broad range of training opportunities is support and guidance from Clinical Advisors and Education Supervisors who are on-hand to encourage and empower you to realise your ambitions.

If you're looking to enhance and diversify your clinical expertise in a role that challenges you to your full potential, consider joining Rodericks Dental - the sky's the limit!

For more information on the career opportunities available at Rodericks visit www.rodericksdentalcareers.co.uk, or contact Ashley Lillyman at recruitment@ rodericksdental.co.uk or on 01604970988 (option 1).

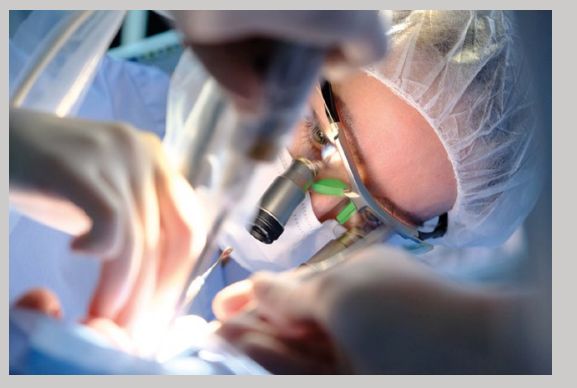

\section{Want to be greener? Outsource payroll!}

Outsource your payroll and you'll save paper waste and make the process more energy-efficient - what a way to be greener!

Wagemate is a specialist provider that uses Cloud-based technology to deliver your payroll every month. We will fully manage the task, including employee pensions and ensuring that you are compliant for HMRC.

The service from Wagemate is secure, risk free and great for your practice's commitment to reduce its carbon footprint. Our clients love our ePayslips portal, which allows them to generate paperless payslips.

To better manage your payroll, contact payroll specialists Wagemate on 03330 102102 or email info@wagemate.com.

\section{Tried, tested and optimised}

All visor systems from Nuview are tried and tested to ensure compliance with any relevant standards and regulations. More than this, solutions are designed to optimise comfort, efficiency and peace of mind for patient and practitioner.

The Nuview Headband Loupe Visor, for example, features an extended visor area to accommodate the whole loupe and mounted light with ease. The headband mounted visor avoids the need for additional accessories, superior optical quality delivers clarity and the easily detachable visor mount makes cleaning simple. Competitively priced as well, the Nuview Headband Loupe Visor represents excellent value for a winning investment in your PPE and patient safety.

Contact the expert team at Nuview for more details on 01453 872266, email info@ nuview-ltd.com, visit www.nuview.co or 'like' Nuview on Facebook.

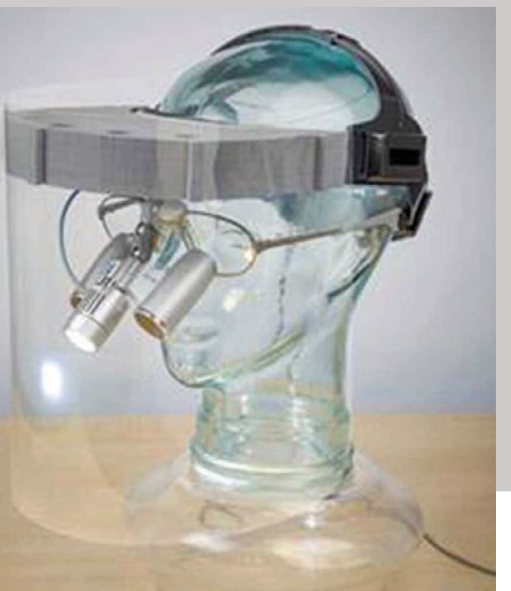

